\title{
Variation of lichen communities with landuse in Aberdeenshire, UK
}

\author{
Patricia A. WOLSELEY, Silvia STOFER, Ruth MITCHELL, \\ Anne-Marie TRUSCOTT, Adam VANBERGEN, James CHIMONIDES \\ and Christoph SCHEIDEGGER
}

\begin{abstract}
The distribution of lichen species in upland regions of Aberdeenshire, Scotland, is investigated along a landuse gradient from natural forest to intensive agriculture. Quantitative data on lichen communities on saxicolous, epiphytic and terricolous substrata were collected from 16 hectare in one $\mathrm{km}^{2}$ in each landuse type. Multivariate analyses, NMDS and Cluster analysis were used to identify lichen communities associated with environmental factors including landuse, substratum type and age. The epiphytic community of native pinewoods was distinguished from all others by the highest species richness, the presence of indicators of ecological continuity and the absence of nitrophytes, while the epiphytic communities of farmland were distinguished by absence of acidophytes and a high contribution of nitrophytes. Plantations of conifers were distinguished by low species richness and an increase in tolerant species. Saxicolous communities were frequent on walls in all sites except native pinewood, where saxicolous substrata were rare. Intensively farmed sites were distinguished by an increase in percentage contribution of nitrophytes. The high acidophyte contribution in all sites suggests that crustose species of acid rocks may not respond rapidly to an increase in applied nitrogen. In landscapes where tree cover is sparse or non-existent combined assessment of habitat diversity and nitrophyte indicator species can be used to assess changes associated with agricultural intensification.
\end{abstract}

Key words: acidophyte, agriculture, forestry, nitrophyte, species richness.

\section{Introduction}

Lichens are widespread in natural and man-made habitats, but occur in distinct communities associated with variations in macro- and micro-habitat, atmospheric conditions and substratum characteristics (James et al. 1977). In Europe lichens have been used as bio-indicators of changes associated with short and long range deposition of atmospheric pollutants from industry and fossil fuel burning (van Haluwyn \& van Herk 2002), ammonia from intensive farming

P. A. Wolseley and J. Chimonides: The Natural History Museum, Cromwell Rd, London SW7 5BD, UK.

S. Stofer and C. Scheidegger: Swiss Federal Institute for Forest, Snow and Landscape Research, Zücherstrasse 111, Birmensdorf CH-8903, Switzerland.

R. Mitchell, A.-M. Truscott and A. Vanbergen: Centre for Ecology and Hydrology, Hill of Brathens, Banchory, Aberdeenshire AB31 4BW, UK. (van Herk 1999, 2002; Sutton et al., 2004a) and ammonium products from agricultural sources (van Herk et al. 2003). The use of defined epiphytic indicator species for assessing atmospheric conditions has been developed by van Herk et al. (1999, 2002) using species defined as acidophytes and nitrophytes. This method has also been shown to be useful in Britain for detecting increased atmospheric ammonia in areas of agricultural intensification (Wolseley et al. 2006). Their sensitivity to changes in environmental conditions has led to their use as indicators of habitats of special conservation interest in particular the use of selected epiphytic species to develop indices of ecological continuity for both deciduous forests and native pinewoods (Rose 1992; Coppins \& Coppins 2002). These indices, based on presence of indicator species, provide a method of rapid assessment of sites of 
conservation interest in wooded habitats (Rose 1992), but cannot be used to detect shifts in frequency or of changes in community composition, nor do they allow comparison of changes in diversity on a range of substrata. More recently the response of epiphytic lichen communities to increasing ammonia from intensive agriculture has been used to develop a scale based on indicator species (van Herk 1999, 2002). Crustose saxicolous lichens may be extremely long-lived and have been used as a method of dating man-made structures and geomorphological events (Innes 1988; McCarthy 2002). In montane and upland habitats where epiphytic diversity is often low their contribution to species diversity is high, and includes species that are restricted in their distribution. However, despite the abundance of saxicolous species on walls in upland farmed habitats, saxicolous indicators of nutrient increase have not been assessed, other than the description of nutrient dependent ornithocoprophilous communities (Armstrong 1994; James et al. 1977). The application of a strict sampling procedure that was suggested for a European research project BioAssess allowed us to compare lichen diversity and species content of both epiphytic and saxicolous communities across a range of environmental conditions.

The use of a simple quantitative method of sampling on different substrata in a $1 \mathrm{~km}$ square allows a direct comparison between lichen communities, substratum and habitat diversity with land management (Scheidegger et al. 2002).

The objective of this study was to identify changes in characteristic epiphytic, saxicolous and terricolous lichen communities along a landuse gradient from natural forest to intensive agriculture in selected sites in Aberdeenshire, Scotland.

\section{Methods}

\section{Study area}

This study is part of an EU funded project (BioAssess) set up to estimate biodiversity of selected groups of flora and fauna under differing land management regimes. In eight European countries $1 \mathrm{~km}^{2}$ units were selected within 6 specified land management regimes across a gradient from natural forest of the area (LUU1), to plantation (LUU2), to mixed use dominated by forest (LUU3), mixed use dominated by pasture (LUU4) to grassland (LUU5) and arable (LUU6) (Bergamini et al. 2005; Stofer et al. 2006). The UK sites were in Aberdeenshire in Scotland on granite bedrock, and included native Caledonian pine forest, plantation forest of conifers, mixed forest and agricultural grassland and arable farms (Fig. 1). This part of Scotland consists of large estates often containing several landuse types within a complex so that a $1 \mathrm{~km}^{2}$ grid square may only include a small portion of a working unit. Sites 1 and 4 are on the Glen Tanar Estate, sites 3 and 5 on the Finzean Estate, site 2 in community woodland formerly part of the extensive forest that covered this area (Anon. 2001), and site 6, a mixed farm, on the MacRobert Estate. Site 1 is in the Forest of Glen Tanar, a National Nature Reserve within an extensive area of open Scots pine woodland on NE and SW facing slopes of the waters of Allarchy.

\section{Phorophytes}

The Scots pine (Pinus sylvestris L.) is the dominant native tree of the upland areas together with Larix decidua and Betula species. Broadleaved trees are found in the valley bottoms especially along the rivers as at Craskins (LUU6) and Woodend (LUU3) where Quercus, Alnus, Fraxinus and Prunus padus were frequent together with Betula species. Plantations of European larch were frequent in farmland (LUU4), in moorland (Birse-LUU2) and as replanted forestry (LUU2). Species names and girth of all trees were recorded.

\section{Saxicolous sites}

Rock outcrops were rare in all sites, being absent from the $1 \mathrm{~km}^{2}$ grid square in Glen Tanar except for occasional boulders along the stream margins. In contrast, man-made saxicolous objects were frequent in agricultural sites, where field walls and boulders are the main habitat for saxicolous species. The major period of land clearance in this region was 1770-1870 when drystone walls with capstones were built (Anon. 2001). Land drainage was often undertaken at the same time using a ditch and bank (LUU5) or ditches concealed below walls (LUU6). By 1880 this type of wall building was at an end and walls were frequently replaced with a wire fence and left to disintegrate or a post and wire fence was added to the wall top. Once heavy machinery became available boulder clearance from fields began in earnest in the post 2 nd World War era, and the boulders left on the edge of fields. Soil habitats are often transitory in farmed situations where ground is regularly disturbed for arable or grass leys. In wooded areas there were also few habitats occupied by terricolous species owing to dominant vascular and bryophyte cover.

\section{Sampling methods}

Within each $1 \mathrm{~km}^{2}$ grid square a 16 point grid was established (Fig. 1). Sampling for epiphytic and terricolous lichens was undertaken in 1 hectare centered 


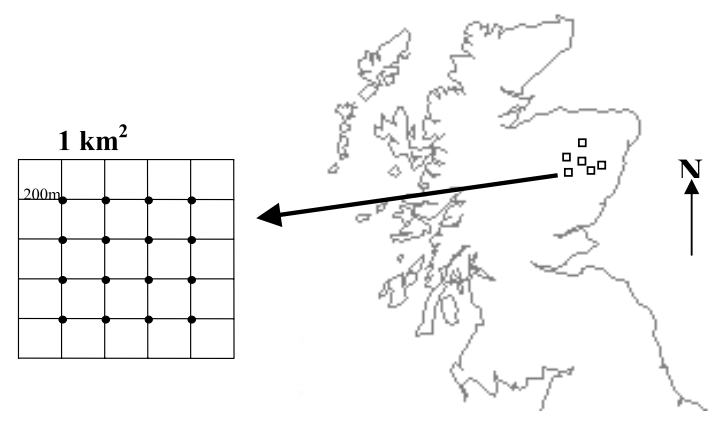

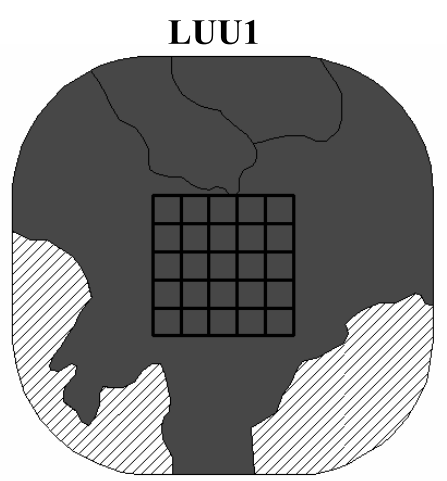
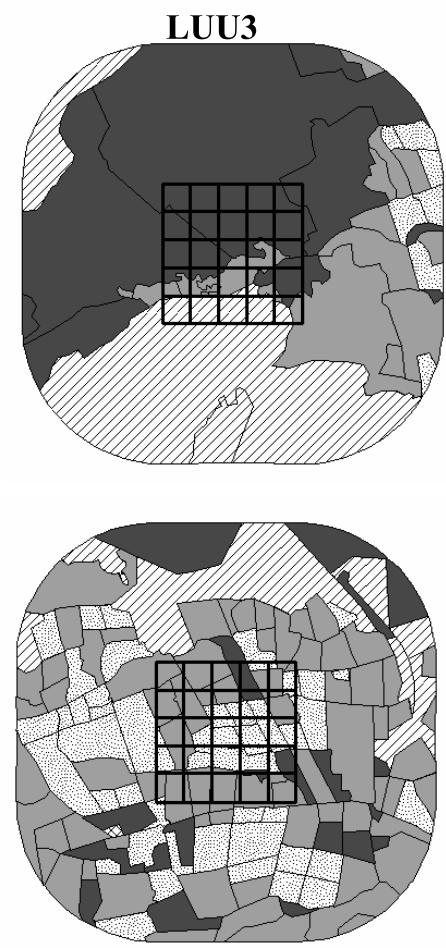

LUU5
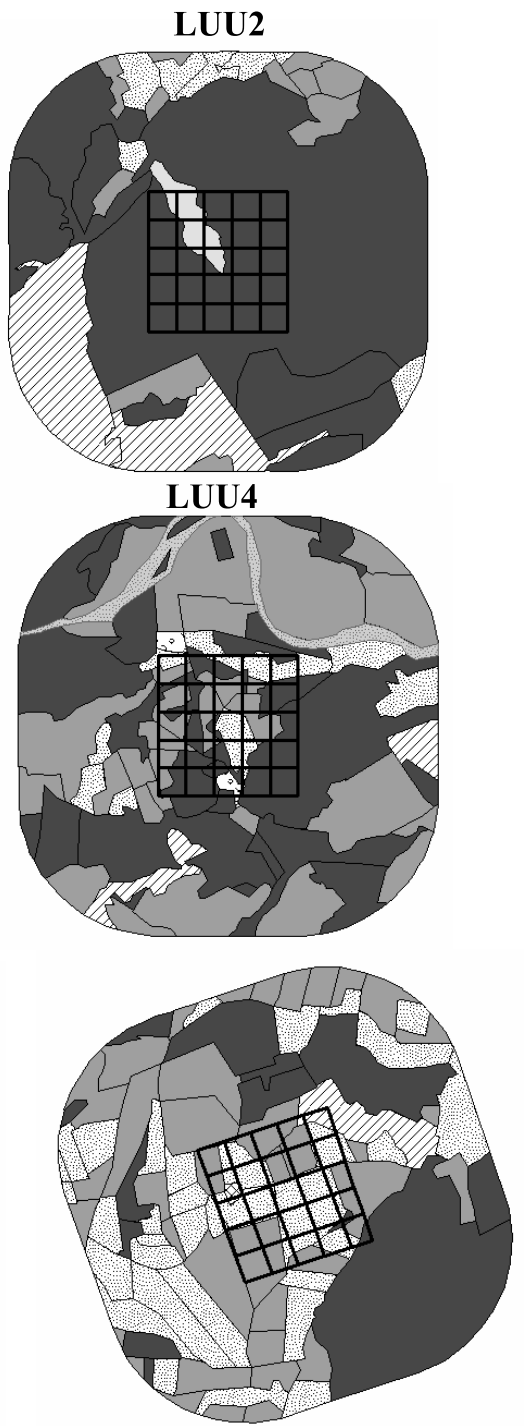

LUU6 a Agro - forestry

$\rightarrow$ Arable cropping

$\square$ Forest

$\square$ Grassland

$\square]$ Heathland

... Water body

Cleared forest

Artificial surfaces

FIg. 1. Location of land use units (LUUs) in Aberdeenshire Scotland UK, showing position of $1 \mathrm{~km}$ grid squares and of 16 one hectare sampling points at the intersections of the grid, landscape heterogeneity within each LUU and its surrounding area. These images were produced with ARCGIS using a fused satellite image (Landsat TM and IRS) of the study area (Vanbergen et al. 2005). 
on each grid point using the method described in Scheidegger et al. (2002). This was based on randomly selected distances along 12 radial compass directions, where terricolous substrata were checked on the grid point using a quadrat with $20100 \mathrm{~cm}^{2}$ squares and the nearest saxicolous and epiphytic objects within the hectare were sampled using 4 ladders with 5 contiguous $100 \mathrm{~cm}^{2}$ so that $2000 \mathrm{~cm}^{2}$ was sampled on each substratum. In each $1 \mathrm{~km}^{2}$ grid square it was possible to sample $192(12 \times 16)$ rocks, trees and terricolous substrata depending on availability. Tree species were identified and girth measured, aspect and type of saxicolous substrata were recorded and where possible date and type of construction. These were classified into categories, from bedrock to boulders including clearance boulders, rubble walls, roadside walls, field walls and walls with bank and ditch. Land management types assigned included arable, silage, setaside, pasture ley, old pasture, moorland, plantation conifer, Caledonian pine forest, and deciduous woodland.

Material collected was identified at CEH Banchory, by Brian Coppins at RBGE and by the first author at the Natural History Museum, London. Names used follow the checklist of lichens from Great Britain and Ireland (Coppins 2002). Species were assigned to acidophyte, nitrophyte, and tolerant categories for epiphytes from van Herk (2002), Wolseley et al. (2004), Sparrius (in press), and for saxicolous species using Purvis et al. 1992.

\section{Data entry and evaluation}

All data were entered in a data base prepared for BioAssess participants, frequency being assessed from presence in 20 squares of a $100 \mathrm{~cm}^{2}$ sample. Multivariate analysis was carried out on all data and on epiphytic and saxicolous data separately at the hectare level using PRIMER 5 and 6 (Clarke \& Warwick 2001). Non-Metric Multi Dimensional Scaling (NMDS), and Cluster Analysis (CA) to establish similarities and differences between lichen components, sites, hectares and sampling points. Similarity of hectares was estimated based on average frequency of all species in each hectare. In NMDS and Cluster Analysis, the Bray-Curtis coefficient of similarity was used. The species compositions involved in groups identified from the cluster analysis were elucidated using the SIMPER (SIMilarity PERcentage contribution) routine in PRIMER. Using the Bray Curtis measure, SIMPER 'computes the average (dis)similarity between all pairs of inter-group samples and then breaks this average down into the separate contributions from each species, both in respect of contributions to the average similarity within a group (i.e. what species and their abundances tend to characterize the groups) and average dissimilarity between groups' (i.e. what species and their abundances tend to separate them). In order to detect changes due to age and type of substratum an analysis of saxicolous data from each sample point in each hectare was undertaken and groups with similarities $>40 \%$ identified.

\section{Results \\ Total lichen species richness}

In six $1 \mathrm{~km}^{2}$ grid squares in Aberdeenshire 258 lichen species were recorded representing $1 / 6$ th of the species richness in the UK. Species richness on all substrata was highest in mixed management sites. Average epiphytic species richness was highest in Caledonian pine forest, including species not found elsewhere, and lowest in farmland sites owing to sparse tree cover or even-aged plantations (Table 2, Fig. 2). Where habitat diversity was high, total species richness was also high as in LUU3 (Tables 1 \& 2, Fig. 3). Saxicolous species richness was lowest in the Caledonian pine forest where outcrops were absent and boulders infrequent, and highest in LUU3 where walls occurred in woodland and farmland together with outcrops in moorland. It was also relatively high in farmland sites in LUUs 4,5 \& 6 (Table 2). Terricolous species richness was low in all sites (Table 2), owing to woodland being moss-dominated and the constant disturbance of agricultural sites. This data set was too small to include in the analysis.

Multi-dimensional scaling (NMDS) of lichen data from all substrata demonstrates: the dissimilarity of the epiphytic lichen community in the Caledonian pine forest from all other sites (Fig. 4A); the distribution of all other samples along a gradient from plantation woodland to arable; the similarity of arable (LUU6) and silage (LUU5) sites; and the wide scatter of samples from LUU3 where habitats ranged from riverside to pasture to plantation, wood pasture and open moorland.

The percentage of habitat types sampled in each $1 \mathrm{~km}^{2}$ grid square (Table 1) illustrates the homogeneity of the Caledonian pine forest where the landscape scale was extensive and the heterogeneity of mixed landscapes where a diversity of habitats was sampled within $1 \mathrm{~km}^{2}$ (Fig. 1, Table 1). The availability of substrata as percentage objects sampled illustrates the paucity of trees and absence of outcrops in farmed landscapes, where lichens are mainly limited to man-made or altered substrata. Clearance boulders 


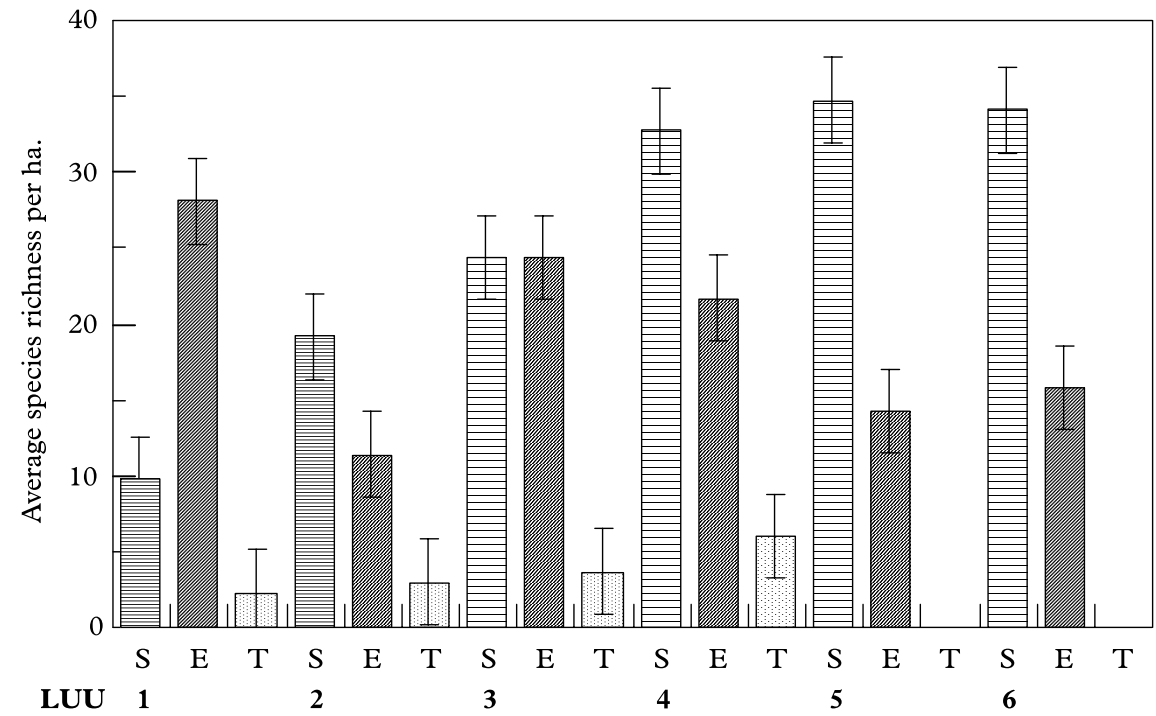

FIG. 2. Average species richness per $\mathrm{km}^{2}$ (Bergamini et al., 2005) of saxicolous (S), epiphytic (E) and terricolous (T) lichens in each LUU.

TABLE 1. Distribution of habitat types within LUUs by percentage area sampled and by percentage objects sampled

\begin{tabular}{|c|c|c|c|c|c|c|}
\hline & LUU 1 & LUU 2 & LUU 3 & LUU 4 & LUU 5 & LUU 6 \\
\hline \multicolumn{7}{|l|}{$\%$ area sampled } \\
\hline natural woodland & 100 & - & 9 & 12 & 1 & 4 \\
\hline plantation & - & 100 & 52 & 23 & 2 & - \\
\hline pasture & - & - & 24 & 57 & 33 & 33 \\
\hline arable/silage & - & - & - & 2 & 58 & 53 \\
\hline roads, quarries etc & - & - & 8 & - & 5 & 7 \\
\hline river or stream & - & - & 5 & - & 1 & 2 \\
\hline \multicolumn{7}{|l|}{$\%$ objects sampled } \\
\hline conifer & 100 & 72 & 25 & 19 & - & - \\
\hline deciduous & - & 22 & 72 & 62 & 9 & 14 \\
\hline rock outcrop & 2 & 3 & 7 & 1 & - & - \\
\hline clearance boulder & 5 & 77 & 66 & 56 & 15 & 16 \\
\hline old boundary wall & - & 6 & 7 & 28 & 43 & 67 \\
\hline rubble field wall & - & - & - & 2 & 32 & 10 \\
\hline
\end{tabular}

formed a large percentage of saxicolous sites in plantations where moorland or forest had been deep-ploughed and in farmland where heavy machinery was more recently available to clear boulders from agricultural land.

\section{Epiphytic lichen groups}

Epiphytic samples fall into 4 clear groups using NMDS with 3 sites falling outside these groups (Fig. 4B). Ep-1 and Ep-6 are discounted as outliers containing less than 2 samples per group. The 4 main groups represent characteristic communities comprising acidophyte, nitrophyte and tolerant species. Species with contributions $>4 \%$ to each group are shown in Table 3 and the distribution of groups in LUUs is shown in Table 4 . The 4 groups include; a community of strongly acidophytic species of native Caledonian pine forests (Ep-3 in LUU1) contrasting with a nitrophytic community on 
TABLE 2. Distribution of species richness by LUU

\begin{tabular}{lrrrrrr}
\hline & LUU 1 & LUU 2 & LUU 3 & LUU 4 & LUU 5 & LUU 6 \\
\hline Ecological group & & & & & & \\
$\quad$ Epiphytic & 61 & 38 & 66 & 57 & 39 & 26 \\
Saxicolous & 5 & 22 & 53 & 44 & 50 & 47 \\
Terricolous & 7 & 6 & 9 & 12 & 1 & 3 \\
\hline
\end{tabular}

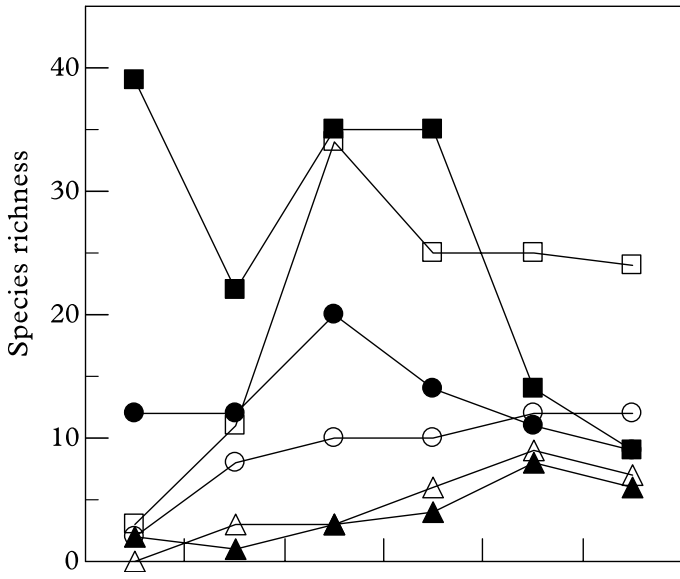

LUU1 LUU2 LUU3 LUU4 LUU5 LUU6

FIg. 3. Total species richness of acidophytes (A), nitrophytes $(\mathrm{N})$ and tolerant species $(\mathrm{T})$ amongst epiphytic (E) and saxicolous (S) lichens in each LUU. AE

$$
\boldsymbol{\square} \text {, AS } \square \text {, NE } \boldsymbol{\Delta} \text {, NS } \triangle \text {, TE } \bullet \text {, TS } \bigcirc \text {. }
$$

trees in farms managed for silage or crops (Ep-2 in LUUs 5 \& 6) a low diversity acidophyte community characteristic of young even-aged plantations (Ep-4 in LUUs 2,3 and one in 4), and a mixed community of nitrogen tolerant species associated with deciduous trees (Ep-5 in LUUs 3, 4 and one in 6). The acidophyte community of the Caledonian pine forest shows the strongest internal similarity of all the groups identified (Bray-Curtis similarity $=64.9 \%$ ) and the greatest dissimilarity with the nitrophyte community $(95 \cdot 6 \%)$, caused by the presence of old forest indicators that often contribute $<4 \%$ to the group. Two species occurring frequently in the nitrophyte community, Evernia prunastri and Parmelia saxatilis are regarded by van Herk (2002) as acidophytes in the Netherlands but their frequent occurrence in the nitrophyte community suggests that in Scotland they may be tolerant of nutrient enrichment. However, within-group similarity is lowest in the nitrophyte group (42.67\%), this being characteristic of a community undergoing change. Ep-4, the low diversity acidophyte group, is conspicuous by the absence of nitrophytes and the dominance of species associated with young acid-barked trees in coniferous plantations. However one of the interesting features of this group is the presence of the rare Vulpicida pinastri in plantation larch in LUU2. This site suffered deforestation prior to replanting, but had not had a change of landuse, and had been replanted in parts with native Larix decidua which had been present in the original forest (Anon. 2001) and where Vulpicida occurred.

In the epiphytic habitat the loss of species associated with ancient pines was most conspicuous, as these species were rarely found in managed habitats. On each tree the same area was sampled and a conspicuous feature associated with loss of species richness is the increase in percentage contribution of a few species such as Hypogymnia physodes, Micarea micrococca and Lecanora pulicaris. In the species-rich sites there is a marked increase in numbers of species with percentage contributions $<1$.

\section{Saxicolous lichen groups}

Granite is a nutrient-poor substratum that naturally supports a highly acidophytic lichen community of foliose and crustose species characteristic of upland Britain. The majority of samples are on man-made objects, such as walls or clearance boulders, except for a few small outcrops in LUU2 and LUU3, and in LUU1 where saxicolous 

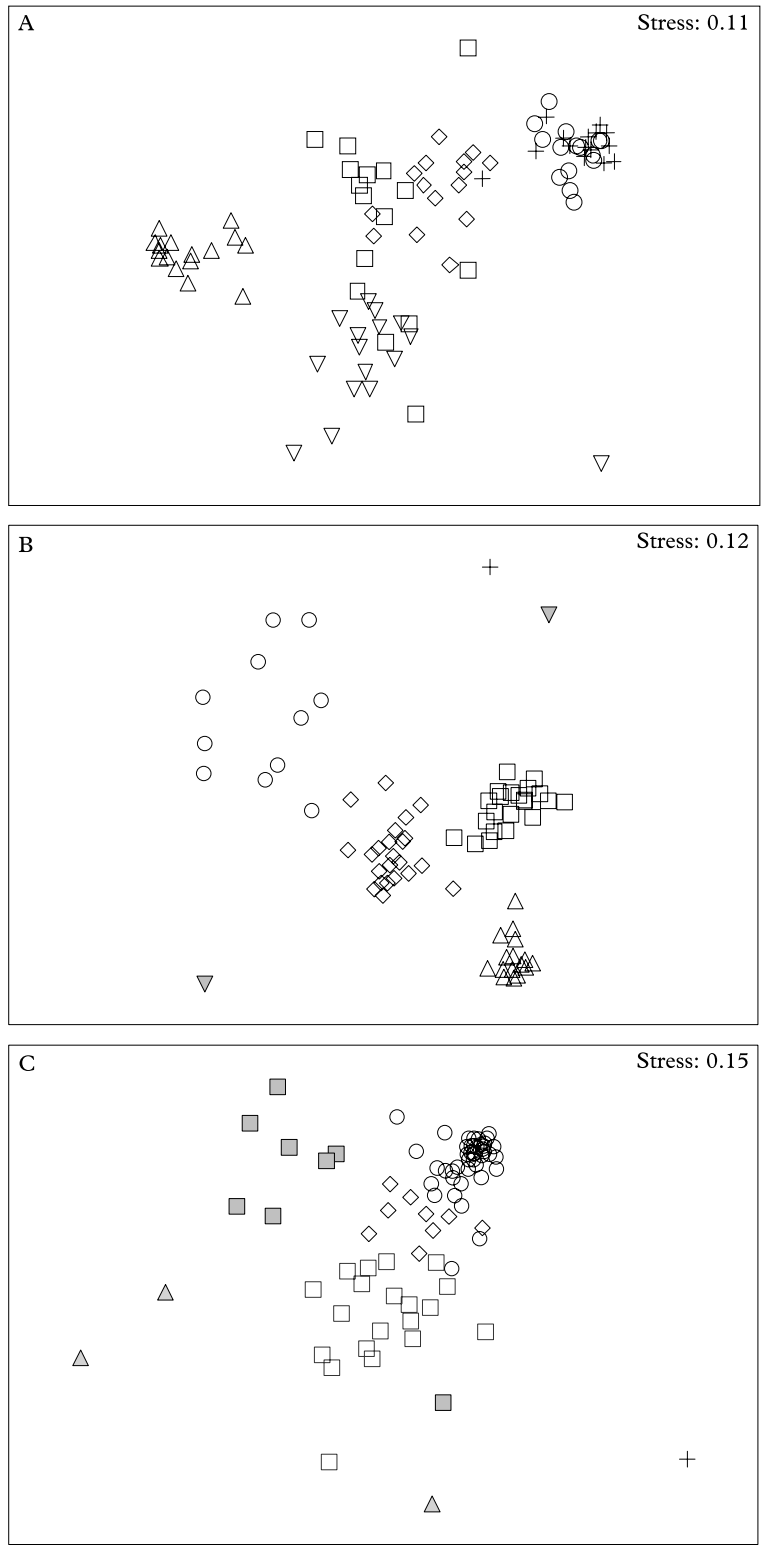

FIG. 4. Non-Metric Multi-Dimensional Scaling. A, NMDS of lichen communities in each hectare $(n=96)$; natural pine forest LUU1 $\triangle$, arable LUU5 + and silage sites LUU6 $\nabla$, conifer plantation LUU2 $\bigcirc$, mixed sites LUU3 $\square$ and LUU4 $\diamond$, stress indicates a measure of the ability of the program to resolve differences in the data; B, NMDS of similarity of epiphytic lichens in each hectare $(n=96)$ distinguished by groups, Ep $3 \triangle$, Ep $4 \square$, Ep 5 $\diamond$, and Ep $2 \bigcirc$, samples outside groups are shown by + and $\mathbf{\nabla}$; C, NMDS of saxicolous lichen similarity in each hectare $(n=96)$ distinguished by groups LUU1 +, Sa $2 \bigcirc$, Sa $3 \diamond$, Sa $4 \square$, Sa $5 \mathbf{\square}$ and Sa $6 \boldsymbol{\Delta}$ (see Table 6).

lichen communities were limited to a few exposed boulders in valley bottoms or open woodland. Unfortunately, saxicolous sites were almost absent from LUU1 so that we could not test the gradient from natural rock exposures to man-made substrata. Six 
TABLE 3. Principal epiphytic lichen species in epiphytic groups identified by SIMPER (*i.e. species with \% contribution $>4 \%$ in at least one group; values $>4 \%$ are shown in bold). Total species number and \% contributions to various subgroups are also given

\begin{tabular}{|c|c|c|c|c|c|}
\hline Epiphytic species & Type & Ep-2 & Ep-3 & Ep-4 & Ep-5 \\
\hline Bryoria fuscescens & A & - & 5 & 0.03 & $1 \cdot 7$ \\
\hline B. subcana & A & - & $6 \cdot 7$ & $0 \cdot 4$ & $1 \cdot 7$ \\
\hline Chrysothrix flavovirens & A & - & $4 \cdot 6$ & - & - \\
\hline Evernia prunastri & A & $4 \cdot 3$ & & $2 \cdot 9$ & $16 \cdot 5$ \\
\hline Hypocoenomyce friesii & A & - & $4 \cdot 4$ & - & $0 \cdot 01$ \\
\hline H. scalaris & A & - & $12 \cdot 7$ & - & $0 \cdot 2$ \\
\hline Hypogymnia physodes & A & - & $22 \cdot 1$ & $45 \cdot 2$ & $20 \cdot 7$ \\
\hline Lepraria rigidula & A & - & $3 \cdot 6$ & $5 \cdot 3$ & - \\
\hline Platismatia glauca & $\mathrm{A}$ & - & $5 \cdot 1$ & $0 \cdot 25$ & - \\
\hline Pseudevernia furfuracea & A & - & 4 & $0 \cdot 5$ & $0 \cdot 6$ \\
\hline Usnea hirta & A & - & $4 \cdot 7$ & 1 & $1 \cdot 8$ \\
\hline Amandinea punctata & $\mathrm{N}$ & 6 & - & - & - \\
\hline Physcia tenella & $\mathrm{N}$ & $9 \cdot 6$ & - & - & 0.03 \\
\hline Scoliciosporum chlorococcum & $\mathrm{N}$ & $7 \cdot 8$ & - & 0.06 & $0 \cdot 11$ \\
\hline Xanthoria polycarpa & $\mathrm{N}$ & $10 \cdot 2$ & - & - & $0 \cdot 1$ \\
\hline Lecanora chlarotera & $\mathrm{T}$ & $8 \cdot 46$ & $0 \cdot 01$ & 0.02 & - \\
\hline L. expallens & $\mathrm{T}$ & $7 \cdot 5$ & $0 \cdot 1$ & $0 \cdot 2$ & $4 \cdot 2$ \\
\hline L. pulicaris & $\mathrm{T}$ & - & - & $13 \cdot 2$ & $7 \cdot 1$ \\
\hline Lecidella elaeochroma & $\mathrm{T}$ & 4 & - & - & $0 \cdot 04$ \\
\hline Melanelia subaurifera & $\mathrm{T}$ & $2 \cdot 9$ & $0 \cdot 01$ & $0 \cdot 2$ & $8 \cdot 4$ \\
\hline Parmelia sulcata & $\mathrm{T}$ & $15 \cdot 8$ & - & $0 \cdot 1$ & $5 \cdot 9$ \\
\hline Ramalina farinacea & $\mathrm{T}$ & $7 \cdot 6$ & - & 0.05 & $0 \cdot 7$ \\
\hline Total $\%$ contribution of $\mathrm{spp}>4 \%$ & & $84 \cdot 16$ & $73 \cdot 02$ & $69 \cdot 41$ & $69 \cdot 79$ \\
\hline Species contribution of others $<4 \%$ & & $15 \cdot 94$ & $26 \cdot 98$ & $30 \cdot 59$ & $30 \cdot 21$ \\
\hline Total no. of species & & 28 & 48 & 33 & 61 \\
\hline Total $\%$ contribution of acidophytes & A & $7 \cdot 87$ & $97 \cdot 57$ & $59 \cdot 39$ & $48 \cdot 91$ \\
\hline Total \% contribution of nitrophytes & $\mathrm{N}$ & $39 \cdot 02$ & 0 & 0.06 & $1 \cdot 14$ \\
\hline Total $\%$ contribution of others & $\mathrm{T}$ & $45 \cdot 26$ & $0 \cdot 12$ & $13 \cdot 77$ & $26 \cdot 34$ \\
\hline
\end{tabular}

${ }^{\star} \mathrm{A}$ - acidophytes, $\mathrm{N}$-nitrophytes, $\mathrm{T}$ - tolerant.

TABLE 4. Distribution of epiphytic communities in hectares and LUUs

\begin{tabular}{|c|c|c|c|c|c|c|}
\hline Epi site & Ep-1 & Ep-2 & Ep-3 & Ep-4 & Ep-5 & Ep-6 \\
\hline LUU 1 & - & - & 16 & - & - & - \\
\hline LUU 2 & - & - & - & 14 & - & - \\
\hline LUU 3 & - & - & - & 6 & 9 & 1 \\
\hline LUU 4 & - & - & - & 1 & 13 & 1 \\
\hline LUU 5 & - & 8 & - & - & - & - \\
\hline LUU 6 & 1 & 3 & - & - & 1 & - \\
\hline
\end{tabular}

groups were identified but 1 and 6 are excluded from Table 6 , Sa-1 having one sample in LUU1 and Sa-6 having 3 samples on boulders in LUUs 1 and 2, distinguished by the presence of Cladonia pyxidata and bryophytes.
An NMDS of sampled hectares by lichen frequency also identified 4 groups (Fig. 4C). Acidophyte species characteristic of granite rocks were present in all groups but the species composition and proportion of acidophyte, nitrophyte and tolerant species 
TABLE 5. Principal saxicolous lichen species ${ }^{\star}$ in saxicolous groups identified by SIMPER ( ${ }^{*}$ i.e. species with \% contributions $>4 \%$ in at least one group; values $>4 \%$ are shown in bold). Total species number and \% contributions to various subgroups are also given

\begin{tabular}{|c|c|c|c|c|c|}
\hline Saxicolous species & Type & $\mathrm{Sa}-2$ & $\mathrm{Sa}-3$ & $\mathrm{Sa}-4$ & Sa-5 \\
\hline Baeomyces rufus & A & $0 \cdot 13$ & $1 \cdot 5$ & $17 \cdot 5$ & $1 \cdot 4$ \\
\hline Lepraria lobificans & A & $0 \cdot 02$ & $0 \cdot 8$ & $9 \cdot 3$ & - \\
\hline Parmelia saxatilis & A & $11 \cdot 7$ & $21 \cdot 4$ & $13 \cdot 1$ & $3 \cdot 2$ \\
\hline Porpidia cinereoatra & A & $0 \cdot 9$ & $1 \cdot 3$ & $8 \cdot 9$ & $0 \cdot 9$ \\
\hline P. crustulata & A & $0 \cdot 1$ & $0 \cdot 8$ & $0 \cdot 2$ & $12 \cdot 5$ \\
\hline Rhizocarpon geographicum & A & $8 \cdot 9$ & $7 \cdot 7$ & - & $4 \cdot 34$ \\
\hline Acarospora fuscata & $\mathrm{N}$ & $6 \cdot 5$ & $2 \cdot 3$ & $0 \cdot 3$ & - \\
\hline Candelariella vitellina & $\mathrm{N}$ & $5 \cdot 7$ & - & - & - \\
\hline Lecanora polytropa & $\mathrm{T}$ & $9 \cdot 4$ & $7 \cdot 4$ & $2 \cdot 1$ & $11 \cdot 2$ \\
\hline L. rupicola & $\mathrm{T}$ & 5 & $0 \cdot 07$ & - & \\
\hline Melanelia fuliginosa subsp. glabratula & $\mathrm{T}$ & $1 \cdot 6$ & $5 \cdot 1$ & $0 \cdot 4$ & $1 \cdot 3$ \\
\hline Porpidia tuberculosa & $\mathrm{T}$ & $6 \cdot 9$ & $12 \cdot 9$ & $11 \cdot 3$ & $41 \cdot 3$ \\
\hline Rhizocarpon geographicum & $\mathrm{T}$ & $8 \cdot 9$ & $7 \cdot 7$ & - & $4 \cdot 3$ \\
\hline R. reductum & $\mathrm{T}$ & - & $0 \cdot 6$ & $0 \cdot 02$ & $6 \cdot 3$ \\
\hline Total $\%$ contribution of $\mathrm{spp}>4 \%$ & & $65 \cdot 7$ & $68 \cdot 97$ & $63 \cdot 1$ & $80 \cdot 44$ \\
\hline Total $\%$ contribution of $\mathrm{spp}<4 \%$ & & $34 \cdot 3$ & $31 \cdot 03$ & $36 \cdot 9$ & $19 \cdot 56$ \\
\hline Total number of species & & 78 & 50 & 58 & 19 \\
\hline Total $\%$ contribution of acidophytes & A & $37 \cdot 7$ & $63 \cdot 65$ & $76 \cdot 67$ & $30 \cdot 3$ \\
\hline Total $\%$ contribution of nitrophytes & $\mathrm{N}$ & $17 \cdot 2$ & $2 \cdot 5$ & $1 \cdot 83$ & 0 \\
\hline Total \% contribution of 'others' & $\mathrm{T}$ & $36 \cdot 4$ & $33 \cdot 83$ & $20 \cdot 65$ & $69 \cdot 4$ \\
\hline
\end{tabular}

${ }^{\star} \mathrm{A}$-acidophytes, $\mathrm{N}$-nitrophytes, $\mathrm{T}$ - tolerant.

TABLE 6. Distribution of saxicolous samples in hectares by group

\begin{tabular}{|c|c|c|c|c|c|c|}
\hline Sax site & Sa-1 & Sa-2 & Sa-3 & $\mathrm{Sa}-4$ & Sa-5 & Sa-6 \\
\hline LUU 1 & 1 & - & - & 1 & 3 & 2 \\
\hline LUU 2 & - & - & - & 14 & 1 & 1 \\
\hline LUU 3 & - & 1 & 7 & 3 & 4 & - \\
\hline LUU 4 & - & 12 & 1 & 1 & - & - \\
\hline LUU 5 & - & 15 & - & - & - & - \\
\hline LUU 6 & - & 15 & - & - & - & - \\
\hline
\end{tabular}

changed between the groups (Table 5). The group with the largest number of samples was characteristic of walls in arable and silage hectares (Sa-2 in LUUs 4,5 \& 6) where nitrophytes contributed $12 \cdot 2 \%$ and tolerant species $27 \cdot 3 \%$ respectively. This group contained the highest species richness and contrasted with the species-poor group of recently exposed boulders (Sa-5 in LUUs $1,2 \& 3)$ where Porpidia tuberculosa contributed $41 \%$. The other 2 groups are both characteristic of woodland hectares in LUUs 2 and 3 but distinguished by a higher con- tribution of tolerant species in LUU3 (Sa-3) and the high contribution of Baeomyces rufus in LUU2 (Sa-4).

Highest species richness was found on walls in agricultural land where 78 species are recorded in 43 sampled hectares (Sa-2). The similarity within this group is $58 \%$ with a total acidophyte contribution of $37 \cdot 7 \%$, many of these being long-lived crustose species. The total nitrophyte contribution of $16.4 \%$ distinguished this group from the others so that dissimilarity with the other groups was $>80 \%$. Boulders exposed during 
recent deep ploughing carried a characteristic community of rapid colonizers with low species diversity (Sa-5) and an absence of nitrophytes.

The remaining 2 groups comprise a species-rich community of old walls in deciduous woodland along the river in LUU3 with a large number of Cladonia species together with Sphaerophorus globosus (Sa-3), and a species-poor community of recently exposed boulders following deep ploughing of woodland and moorland for plantation in LUU2 (Sa-4). Unlike the epiphytic communities the saxicolous acidophytes were still conspicuous in the nitrophyte community Sa-2 suggesting that they are not as sensitive to increasing nitrogen on the low $\mathrm{pH}$ substratum granite.

The analysis of combined data from each hectare does not take into account variation in the substratum at each sample point. Within each hectare a range of saxicolous substrata from outcrops to walls or recently exposed boulders could be sampled. The analysis of data from each sample point identified 13 groups with similarities $>40 \%$ and an outlier of miscellaneous samples (group 14). Using species occurring in 90 percent of all samples (excluding less frequently occurring species) the percentage of each species contribution to these groups is shown in Table 7 and distribution of groups within LUUs in Table 8.

Characteristics of groups by substratum type, habitat, land management and species component are outlined below.

Group 1 a highly miscellaneous group of 23 samples originating from several levels in the cluster analysis at low similarity, occurring in all sites, mainly on boulders but also on walls and rock outcrops with a diversity of species contributing (Table 7).

Group 2 is a small group of 12 samples occurring on boulders in LUU2, 3, 4 \& 5 characterized by the high occurrence of Lecanora polytropa together with Aspicilia caesiocinerea and Miriquidica leucophaea. This group is associated with plantation and pasture but not with arable, silage or setaside management.
Group 3 of 16 samples is associated with nutrient-enriched boulders and walls in well-lit places mainly in LUU3 but also in 4, 5 and 6 characterized by presence of Acarospora fuscata, Melanelia futiginosa subsp. glabratula and Rhizocarpon geographicum.

Group 4 is a small set of 6 samples which are similar to group 3 with a high \% of the nitrophyte Candelariella vitellina together with Acarospora fuscata, Rhizocarpon reductum and Scoliciosporum umbrinum associated with boulders and walls on farm sites where bird-perching stones are used regularly.

Group 5 containing 100 samples is found on horizontal surfaces of walls and boulders mainly in LUUs 3 and 4 in contrast with Group 6 and dominated by the foliose species Parmelia saxatilis. No other distinguishing species were found in this group.

Groups 6 and 7 share c. $53 \%$ similarity, but group 6 contains 349 samples mainly on walls in LUUs 5 and 6 characterized by the presence of nitrophytes Candelariella vitellina and Acaraospora fuscata together with acidophytes such as Parmelia saxatilis and other nutrient tolerant acidophytes. This group is found on walls in pasture, arable, setaside and silage managements. Group 7 is small (15 samples) occurring on boulders (often broken down walls!) in pasture in LUU4 and is characterized by absence of nitrophytes and presence of Lecidea lithophila and Rhizocarpon reductum.

Group 8 comprising 62 samples, is found mainly on boulders in LUUs 2, 3 and 4-a species-poor community of boulders from recent clearances in pastures and new plantations of larch, dominated by rapid colonizers such as Porpidia tuberculosa, Lecanora intricata and Lecidea lithophila.

Group 9 comprising 28 samples occurs on old walls and boulders in shaded plantations mainly in LUU2 but also in LUUs 3 and 4 . It is characterized by the presence of Cladonia polydactyla, Sphaerophorus globosus and other shade tolerant 
TABLE 7. Saxicolous species by sample point based on $90 \%$ frequency, showing $\%$ contribution to each group identified from cluster analysis

\begin{tabular}{|c|c|c|c|c|c|c|c|c|c|c|c|c|c|c|c|}
\hline Species & Type ${ }^{\star}$ & Gp 1 & Gp 2 & Gp 3 & Gp 4 & Gp 5 & Gp 6 & Gp 7 & Gp 8 & Gp 9 & Gp 10 & Gp 11 & Gp 12 & Gp 13 & Gp 14 \\
\hline Aspicilia caesiocinerea & A & & $3 \cdot 58$ & - & - & - & - & - & - & - & - & - & - & - & - \\
\hline Baeomyces rufus & A & $6 \cdot 12$ & - & - & - & - & - & - & - & - & $13 \cdot 32$ & $90 \cdot 4$ & - & $5 \cdot 46$ & - \\
\hline Cladonia coniocraea & A & - & - & - & - & - & - & - & - & - & - & - & - & $13 \cdot 43$ & - \\
\hline C. polydactyla & A & - & - & - & - & - & - & - & - & $9 \cdot 46$ & - & - & - & - & - \\
\hline C. pyxidata & A & - & - & - & - & - & - & - & - & - & - & - & - & - & $36 \cdot 92$ \\
\hline Lecidea $\mathrm{sp}$. & $\mathrm{A}$ & $23 \cdot 52$ & - & - & - & - & - & - & - & - & - & - & - & - & - \\
\hline Lecidea lapicida & $\mathrm{A}$ & - & - & - & - & - & - & - & - & - & - & - & - & $3 \cdot 14$ & - \\
\hline Lepraria lobificans & $\mathrm{A}$ & - & - & - & - & - & - & - & - & $5 \cdot 32$ & $46 \cdot 77$ & - & - & - & - \\
\hline Micarea lignaria & $\mathrm{A}$ & $3 \cdot 21$ & - & - & - & - & - & - & - & - & - & - & - & - & - \\
\hline M. myriocarpa & A & - & - & - & - & - & - & - & - & - & - & - & $70 \cdot 43$ & - & - \\
\hline Miriquidica leucophaea & $\mathrm{A}$ & - & $10 \cdot 81$ & - & - & - & - & - & - & - & - & - & - & - & - \\
\hline Parmelia saxatilis & $\mathrm{A}$ & $3 \cdot 26$ & - & - & - & $85 \cdot 59$ & $20 \cdot 14$ & - & - & $69 \cdot 41$ & - & - & - & - & - \\
\hline Placynthiella icmalea & $\mathrm{A}$ & - & - & - & - & - & - & - & - & $2 \cdot 27$ & - & - & - & - & - \\
\hline P. uliginosa & A & $8 \cdot 69$ & - & - & - & - & - & - & - & - & - & - & - & - & - \\
\hline Porpidia cinereoatra & A & - & - & - & - & - & - & - & - & - & $28 \cdot 62$ & - & $22 \cdot 27$ & - & - \\
\hline P. crustulata & $\mathrm{A}$ & - & - & - & - & - & - & - & - & - & - & - & - & $51 \cdot 08$ & - \\
\hline Sphaerophorus globosus & $\mathrm{A}$ & - & - & - & - & - & - & - & - & $1 \cdot 84$ & - & - & - & - & - \\
\hline Acarospora fuscata & $\mathrm{N}$ & - & - & $6 \cdot 02$ & $4 \cdot 05$ & - & $6 \cdot 26$ & - & - & - & - & - & - & - & - \\
\hline Candelariella vitellina & $\mathrm{N}$ & $12 \cdot 06$ & - & - & $67 \cdot 76$ & - & $6 \cdot 31$ & - & - & - & - & - & - & - & - \\
\hline Scoliciosporum umbrinum & $\mathrm{N}$ & $8 \cdot 79$ & - & - & 9 & - & - & - & - & - & - & - & - & - & $35 \cdot 38$ \\
\hline Tephromela atra & $\mathrm{N}$ & - & - & - & $1 \cdot 75$ & - & - & - & - & - & - & - & - & - & - \\
\hline Lecanora intricata & $\mathrm{T}$ & - & - & - & - & - & $17 \cdot 45$ & $2 \cdot 36$ & $7 \cdot 48$ & - & - & - & - & - & - \\
\hline L. polytropa & $\mathrm{T}$ & $2 \cdot 38$ & $74 \cdot 21$ & - & - & $3 \cdot 15$ & $15 \cdot 58$ & $15 \cdot 78$ & - & - & $2 \cdot 16$ & - & - & - & - \\
\hline Melanelia fuliginosa subsp. glabratula & $\mathrm{T}$ & - & - & $20 \cdot 82$ & - & - & - & - & - & - & - & - & - & - & - \\
\hline Porpidia tuberculosa & $\mathrm{T}$ & $7 \cdot 24$ & - & $11 \cdot 5$ & - & $4 \cdot 33$ & $4 \cdot 57$ & $31 \cdot 22$ & $79 \cdot 78$ & - & - & - & - & $19 \cdot 61$ & $22 \cdot 5$ \\
\hline Pertusaria corallina & $\mathrm{T}$ & $3 \cdot 26$ & - & - & - & - & - & - & - & - & - & - & - & - & \\
\hline Rhizocarpon geographicum & $\mathrm{T}$ & - & - & $55 \cdot 88$ & $5 \cdot 07$ & - & $14 \cdot 94$ & $2 \cdot 17$ & - & - & - & - & - & - & - \\
\hline R. reductum & $\mathrm{T}$ & - & - & - & $3 \cdot 74$ & - & $4 \cdot 89$ & $32 \cdot 16$ & - & - & - & - & - & - & - \\
\hline Trapelia involuta & $\mathrm{T}$ & $12 \cdot 02$ & - & - & - & - & - & - & - & - & - & - & - & - & - \\
\hline Trapeliopsis granulosa & $\mathrm{T}$ & $3 \cdot 01$ & $3 \cdot 82$ & - & - & - & - & - & - & $2 \cdot 22$ & - & - & - & - & - \\
\hline
\end{tabular}

${ }^{\star} \mathrm{A}$-acidophytes, $\mathrm{N}$-nitrophytes, $\mathrm{T}$ - tolerant. 


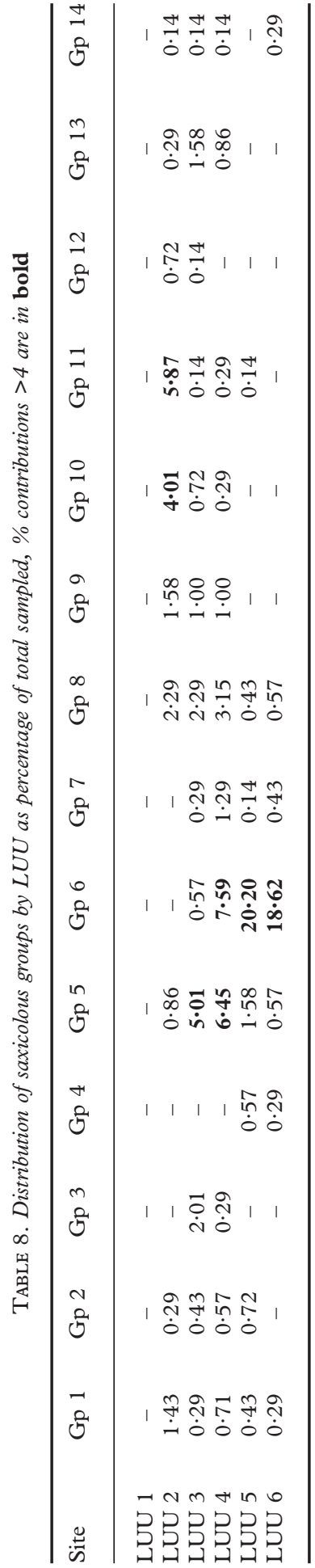

species such as Lepraria lobificans, Placynthiella icmalea and Trapeliopsis granulosa. In the cluster analysis it is closely related to group 5 owing to the high contribution of Parmelia saxatilis.

Group 10 comprising 23 samples occurs in LUU2, and less frequently in LUUs 3 and 4, on boulders exposed during ground clearance in order to plant larch and other conifers $c$. 40 years ago. This group includes rapid colonizers of shaded conditions such as Baeomyces rufus, Porpidia cinereoatra, Lepraria lobificans and Lecanora polytropa.

Group 11 comprising 46 samples in LUU2 is c. $47 \%$ similar to group 10 , also on boulders in the recent plantation of site 2 in darker sites than 10 and charaterized by very low species richness with dominant Baeomyces rufus often associated with a dominant bryophyte cover.

Group 12 is a small group of 6 samples that occurred in site 2 on the overhung sides of boulders with Micarea myriocarpa and Porpidia cinereoatra.

Group 13 comprising 21 samples occurring mainly in LUU3 on boulders and old walls in shaded sites in plantation woodland and pasture characterized by presence of Cladonia coniocraea, Lecidea lapicida and Porpidia crustulata.

Group 14 of 5 samples with low similarity occurring on boulders in LUUs 2, 3, $4 \& 6$ in different land management types characterized by the presence of Cladonia pyxidata and Scoliciosporum umbrinum.

The majority of lichen samples fall into Group 6, a community on agricultural walls mainly in LUUs 5 \& 6 including a conspicuous nitrophyte component together with a highly diverse acidophyte component. The other groups are distinguished by species associated with specific habitats from overhung (Gp. 12) to exposed horizontal rocks (Gp. 5), shaded woodland (Gp. 9) and to recently exposed boulders (Gp. 10). 


\section{Discussion}

\section{Changes in species richness at the local and landscape scale}

The highest epiphytic species richness is associated with mixed use landscapes where a variety of substrata and habitat conditions are available, as in LUU3, where woodland varies from mature deciduous to coniferous and from riverside to moorland and includes old pasture farmland in the valley bottom (Table 1). Indicators of ecological continuity are conspicuously absent in this managed landscape where the species richness is associated with an increase in available substrata and habitats. The species association that contains indicators of ecological continuity is found only in LUU1 mainly on Pinus sylvestris, including ancient, dead or dying trees that support a number of species associated with this specialist habitat including 5 indicators of ecological continuity: Calicium parvum, Chaenotheca chrysocephala, $\mathrm{Hy}$ pocenomyce friesii, Imshaugia aleurites and Lecidea hypopta.

This epiphytic community was formerly very extensive in this region and has largely been lost during two world wars when a high proportion of timber trees was harvested. This was followed by replanting as at LUU2 or establishment of conifers in moorland areas as in parts of LUU3 (Anon. 2001). The conversion to near monoculture plantation forestry is associated with a high dissimilarity between the two acidophyte groups $(67 \cdot 74 \%)$, a conspicuous drop in species richness, and the appearance of rapid colonizers such as Micarea micrococca and Lecanora pulicaris with a percentage contribution of 21 and $13 \cdot 2$, respectively. Epiphytes in agricultural LUUs include nitrophytes at $39.02 \%$ contribution and the near absence of acidophytes (7.87\%) but this is also associated with a change in substratum from conifer to broadleaved phorophyte species with a higher bark $\mathrm{pH}$. There is very little difference in the lichen communities of LUUs 5 and 6 as both are intensively managed, one for a silage crop and the other as a mixed farm with a high arable component. The variation in tree species and tree age in LUUs 3 and 4 contributed to the variation in the lichen communities in these sites.

Saxicolous communities at the hectare level show a rather different pattern as acidophytes and tolerant species contribute the greatest part to species richness in all sites, but the shift to nitrophytes of $16 \cdot 4 \%$ is associated with intensification of agriculture in LUUs 4, 5 and 6. The analysis of saxicolous communities in the pasture site (LUU4), also shows a high contribution of nitrophytes with 12 plots appearing in group 2 (Table 6). This farm is used for cattle rearing and the density of stock may vary, but saxicolous species composition suggests that there is considerable nutrient input. In contrast only one sample from LUU3 falls into group 2 suggesting that changes in LUU3 are not associated with nitrogen. As ammonia is deposited locally within $c$. $200 \mathrm{~m}$ (Fowler et al. 1998) almost all lichen communities will be affected within the $1 \mathrm{~km}^{2}$ grid square, except where geography and wind direction influence deposition. In this situation the saxicolous lichen communities on granite substrata demonstrate the effects of nitrogen on acidophyte lichen communities more effectively than the epiphytic ones where other factors associated with age and type of substratum influence the species richness.

Many of the lichen communities on older farm walls were already closed communities dominated by acidophytes or tolerant crustose species on vertical surfaces. The results of the analysis at sample level placed lichen communities on almost all farm walls in the same group, which differed from the groups on clearance boulders in the same LUUs, suggesting that despite differences in their construction the walls are all of roughly the same age; this is also borne out by historical evidence (Anon. 2001). This community includes samples from ancient boundary walls with large individuals, and with greater diversity including locally rare species. In LUU6 a single colony of Pertusaria aspergilla on a boundary wall measured $75 \mathrm{~cm}$ in diameter, and on the same wall the regionally rare Rhizocarpon simillimum was 
recorded. The increasing nitrogen and dust associated with agriculture does not necessarily kill individuals of these species which may continue to occupy a site for many decades but in higher nitrogen conditions may not be able to establish new colonies. Recent lichen surveys of Stonehenge (Giavarini \& James 2003) have also shown a high component of acidophytes and low contribution of nitrophytes on acid rocks surrounded by an agricultural landscape. In the Netherlands granitic prehistoric monuments have shown an increase in nitrophytes since the 1890s without a loss of the original acidophyte flora (Sparrius \& Aptroot 2003). The appearance of nitrophytes is dependent on a source of spores or propagules and substratum available for colonization. The source of saxicolous nitrophytes in agricultural sites is probably the occasional ornithocoprophilous community below bird perches, often found on walls below a suitable fence post. In the natural upland habitat their occurrence is limited to local sites used by larger birds with a large territory. Foliose species with a rapid turnover can be expected to respond more rapidly to changes in nutrient levels so that tolerant and nitrophyte species such as Physcia species are able to colonize rapidly (Frey 1952). Parmelia saxatilis is considered to be an epiphytic acidophyte (van Herk 2002) but in Scotland it is a dominant component of horizontal saxicolous surfaces on walls in both arable and silage sites, suggesting that it is tolerant of additional nutrients in this region.

These results suggest that frequency of defined nitrophyte lichens could be used as a simple measure of agricultural influence in upland areas on acid rocks. Changes in acidophyte contribution may be more difficult to demonstrate, but may provide indications of long-term changes by way of loss of acidophyte diversity and \% contribution. Recent work on epiphytic communities has shown that the loss of acidophytes is occurring at lower levels of nitrogen pollution than the appearance of nitrophytes (Sutton et al. $2004 b$ ). As the survey did not include a site with natural undisturbed granite outcrops, species loss in this habitat cannot be estimated. A brief visit to outcrops in permanent pasture outside LUU6 produced 6 more saxicolous species that were not found on the farm walls, including species of Bryoria that are known to be sensitive to ammonium deposition (van Herk et al. 2003).

The data analysis of saxicolous lichens at the hectare level may include a variety of saxicolous habitats from boulders to walls and from a range of aspects and inclination. But an analysis of the results from each of the 12 samples in a hectare allows many of these factors to be taken into consideration, such as wall type, aspect, exposure, angle of rock surface from horizontal to overhung (James et al. 1977). The results have shown that lichen communities are very sensitive to microclimatic conditions and that increasing the range of microhabitats available contributes greatly to species richness as shown in LUUs 3 and 4. An analysis of saxicolous communities of a rockfall in the Canadian Rocky Mountains showed differential responses to microenvironmental conditions and identified associations of lichens (John 1989). The contribution of habitat diversity to species richness of lichens is marked and indicates that recording of habitat diversity can act as a surrogate for estimating species richness, while changes in the frequency of indicator species in space and/or time allows assessment of ongoing changes in distribution associated with environmental changes. Changes in the acidophyte communities may suggest long-term effects of intensification, especially those communities containing locally rare species.

\section{Conclusion}

The analysis of epiphytic lichen communities shows the conspicuous difference between natural epiphytic lichen communities of ancient pine forests and those of a range of trees in sites managed for forestry or agriculture. It also demonstrates the association of agricultural intensification with the loss of the acidophyte, and increases in the nitrophyte component of the lichen flora. In the saxicolous sites the acidophyte component 
remained high in all sites, but in sites where intensive agriculture has been undertaken there was a marked increase in nitrophytes on the granite substratum. In many parts of upland Britain trees are rare or absent while saxicolous sites are abundant and contain a major part of the lichen species richness. Habitat loss contributes a major role in the loss of alpha diversity in natural habitats for both epiphytic and saxicolous sites as illustrated by the low epiphytic and saxicolous species richness of the conifer plantations and the absence of indicators of ecological continuity. Where this is not accompanied by a change in tree species and landuse it is possible that rare or local species (e.g. Vulpicida pinastri) may continue to occur. The combined assessment of habitat diversity and percentage contribution of indicator species in both epiphytic and saxicolous communities can be used to assess environmental changes associated with land management and in particular with agricultural intensification.

The authors thank landowners who gave permission for this investigation, Brian Coppins at Royal Botanic Garden Edinburgh for identification and checking of specimens, Peter James for discussion over nutrient status of saxicolous species, and reviewers for improvements to the paper. This study was part of the European Community programme BioAssess and was supported by the European Union (EVK2-1999-00280) and the Swiss Federal Office for Education and Science (EVK2CT-1999-00280, BBW Nr. 99.0683). CS and SS acknowledge funding from the Swiss Federal Office for Education and Science (LACOPE: EVK2-CT-200200150, BBW Nr. 01.0476-1).

\section{REFERENCES}

Anon. 2001 The Statistical Accounts of Birse Parish 1792, 1842, 1950. Birse Community Trust.

Armstrong, R. A. (1994) The influence of bird droppings on the growth of lichen fragments transplanted to slate and cement substrates. Symbiosis 17: 75-86.

Bergamini, A., Scheidegger, C., Stofer, S., Carvalho, P., Davey, S., Dietrich, M., Dubs, F., Farkas, E., Groner, U., Kärkäinen, K., Keller, C., Lökös, L., Lommi, S., Máguas, C., Mitchell, R., Pinho, P., Rico, V., Aragón, G., Truscott, A-M., Wolseley, P., Watt, A. (2005) Performance of macrolichens and lichen genera as indicators of lichen species richness and composition. Conservation Biology 19: 1051-1062.

Clarke K. R. \& Warwick R. M. 2001 Change in Marine Communities: an Approach to Statistical Analysis and
Interpretation 2nd ed. Plymouth: Primer-E, Marine Laboratory.

Coppins, A. M. \& Coppins, B. J. (2002) Indices of Ecological Continuity for Woodland Epiphytic Lichen Habitats in the British Isles. London: British Lichen Society.

Coppins B. J. (2002) Checklist of Lichens of Great Britain and Ireland. London: British Lichen Society.

Fowler D., Pitcairn C. E. R., Sutton M. A., Flechard C., Loubet B., Coyle M. \& Munro R. C. (1998) The mass budget of atmospheric ammonia within $1 \mathrm{~km}$ of livestock buildings. Environmental Pollution 102: S1: 343-348.

Frey, E. (1952) Die Flechtenflora und -vegetation des Nationalparks im Unterengadin; Teil 2: Die Entwicklung der Flechtenvegetation auf photogrammetrisch kontrollierten Dauerflächen. Ergebnsisse der wissenschaftichen Kommission der Schweizerischen Naturforschenden Gesellschaft zur wissenschaftlichen Erforschung des Nationalparks 6: 240-319.

Giavarini, V. \& James, P. W. (2003) Lichen Survey of Stonehenge, Amesbury, Wiltshire. Unpublished report for English Heritage.

Innes, J. L. (1988) The use of lichens in dating. In Handbook of Lichenology (M. Galun, ed.): 75-92. Boca Raton, Florida: CRC Press Inc.,

James, P. W., Hawksworth, D. L. \& Rose, F. (1977) Lichen Communities of the British Isles: a preliminary conspectus. In Lichen Ecology (M. R. D. Seaward, ed.): 295-413. London: Academic Press.

John, E. A. (1989) An assessment of the role of biotic interactions and dynamic processes in the organization of species in a saxicolous lichen community. Canadian fournal of Botany 67: 2025-2037.

McCarthy, D. (2002) Lichenometry. In Monitoring with Lichens-Monitoring Lichens (P. L. Nimis, C. S. Scheidegger \& P. A. Wolseley, eds.): 379-384. Dordrecht: Kluwer.

Purvis, O. W., Coppins, B. J., Hawksworth, D. L., James, P. W. \& Moore, D. M. (Eds) (1992) The Lichen Flora of Great Britain and Ireland. London: Natural History Museum Publications.

Rose, F. (1992) Temperate forest management: its effects on bryophyte and lichen floras and habitats. In Bryophytes and Lichens in a Changing Environment (J. W. Bates \& A. M. Farmer, eds.): 211-233. Oxford: Clarendon Press.

Scheidegger, C., Groner, U., Keller, C. \& Stofer, S. (2002) Biodiversity assessment tools-lichens. In Monitoring with Lichens-Monitoring Lichens (P. L. Nimis, C. Scheidegger \& P. A. Wolseley, eds): 359-365. Dordrecht: Kluwer.

Sparrius, L. (in press) The response of epiphytic lichen communities to decreasing ammonia air concentrations in the Netherlands. Environmental Pollution.

Sparrius, L. B. \& Aptroot, A. (2003) Changes in the lichen flora of megalithic monuments in the Netherlands. Bibliotheca Lichenologica 00: 441-452.

Stofer, S., Bergamini, A., Aragón, G., Carvalho, P., Davey, S., Dietrich, M., Farkas, E., Kärkkäinen, K., Keller, C., Lokös, L., Lommi, S., Máguas, C., 
Mitchell, R., Pinho, P., Rico, V. J., Truscott, A.-M., Wolseley, P. A., Watt, A., Scheidegger, C. (2006) Species richness of lichen functional groups in relation to land use intensity. Lichenologist 38: 331-353.

Sutton, M. A., Leith, I. D., Pitcairn, C .E. R., van Dijk, N., Tang, Y. S., Sheppard, L. J., Dragosits, U., Fowler, D., James, P. W. \& Wolseley, P. A. (2004a) Exposure of ecosystems to atmospheric ammonia in the UK and the development of practical bioindicator methods. In Lichens in a Changing Pollution Environment. English Nature Report 525 (P. W. Lambley \& P. A. Wolseley, eds): 51-62. Peterborough: English Nature.

Sutton, M. A., Pitcairn, C. E. R. \& Whitfield, C. P. (eds). (2004b) Bioindicator and Biomonitoring Methods for Assessing the Effects of Atmospheric Nitrogen on Statutory Nature Conservation Sites. Report for contract no. F90-01-535. JNCC Report 356: 230.

Vanbergen, A. J., Woodcock, B. A., Watt, A. D. \& Niemelä, J. (2005) Effect of land-use heterogeneity on carabid communities at the landscape scale. Ecogeography 28: 3-16.

van Haluwyn, C. \& van Herk, C. M. (2002) Bioindication: the community approach. In Monitoring with Lichens-Monitoring Lichens (P. L. Nimis, C.
Scheidegger \& P. A. Wolseley, eds): 39-64. Dordrecht: Kluwer.

van Herk, C. M. (1999) Mapping of ammonia pollution with epiphytic lichens in the Netherlands. $L i$ chenologist 31: 9-20.

van Herk, C. M. (2002) Epiphytes of wayside trees as an indicator of eutrophication in the Netherlands. In Monitoring with Lichens-Monitoring Lichens (P. L. Nimis, C. Scheidegger \& P. A. Wolseley, eds): Dordrecht: Kluwer.

van Herk, C. M., Mathijssen-Spiekman, E. A. M. \& de Zwart, D. (2003) Long distance nitrogen air pollution effects on lichens in Europe. Lichenologist 35: 347-360.

Wolseley, P. A., James, P., Theobald, M. R. \& Sutton, M. A. (2006). Detecting changes in epiphytic lichen communities in sites affected by atmospheric ammonia from agricultural sources. $L i$ chenologist 38: 161-176.

Wolseley, P. A., James, P. W., Purvis, O. W., Leith, I. D. \& Sutton, M. A. (2004) Bioindicator methods for nitrogen based on community species composition: lichens. In Bioindicator and Biomonitoring Methods for Assessing the Effects of Atmospheric Nitrogen on Statutory Nature Conservation Sites. JNCC Report 356 (M. A. Sutton, C. E. R. Pitcairn \& C. P. Whitfield, eds): 75-86. Peterborough: Joint Nature Conservation Committee. 